\title{
PEMANFAATAN BIJI CIMPEDAK SEBAGAI MINUMAN KESEHATAN DI BERUNTUNG JAYA KELURAHAN SUNGAI TIUNG KECAMATAN CEMPAKA KOTA BANJARBARU
}

\author{
Ratna Restapaty, Rahmi Hidayati dan Sari Wahyunita \\ Prodi Farmasi, STIKES Borneo Lestari \\ E-mail : ratnarestapaty@gmail.com
}

\begin{abstract}
ABSTRAK
Buah cempedak (Artocarpus champeden sp.) merupakan komoditas perkebunan yang memiliki prospek cerah di masa yang akan datang khusunya untuk daerah Kalimantan, karena di samping dapat dimanfaatkan sebagai bahan pangan, dapat diproyeksikan sebagai bahan industri, salah satunya biji cempedak. Kandungan karbohidrat yang dimiliki biji cempedak, berbanding dengan yang ada pada tepung terigu. Selama ini biji dari buah cempedak kebanyakan dibuang, padahal dapat dikembangkan menjadi satu bentuk bahan pangan baru yang dapat dikonsumsi. Mata pencahariaan warga Beruntug Jaya Kel. Sungai Tiung Cempaka sebagaian besar adalah pendulang intan, petani, dan pedagang. Kesejahteraan warga terbatas dan tidak ada usaha mandiri bagi ibu-bu atau remaja perempuan. Kendala yang dihadapi warga (1) Kegiatan posyandu yang sangat belum optimal, (2) belum memiliki keahlian dalam membuat dan memanfaatkan biji cimpedak, (3) Kurangnya pemahamanan terhadap penanganan terhadap ibu menyusui. Permasalahanpermasalahan yang terjadi disebabkan : (1) Kurangnya informasi yang di berikan petugas posyandu tentang hasil-hasil penelitian kesehatan terutama dalam hal pengolahan bahan alam. (2) Rendahnya kemampuan dan keterampilan warga dalam mengolah bahan alam untuk produk minuman atau makanan sehat, (3) Kurangnya informasi bagi ibu tentang produksi ASI. Luaran kegiatan ini adalah : (1) warga dapat menguasai teknik pembuatan susu cimpedak dengan baik. (2) warga memahami komponen gizi dan khasiat biji cimpedak bagi kesehatan, terutama khasiat bagi ibu menyusui.Metode kegiatan yang dilaksanakan adalah (1) pemberian informasi/ teori, (2) demontrasi/ Praktek langsung pembuatan susu biji cimpedak. Khalayak sasaran adalah petugas posyandu dan warga sekitar di desa Beruntung Jaya, Kel Sungai Tiung, Cempaka-Banjarbaru
\end{abstract}

Kata Kunci : Biji Cimpedak, Minuman Sehat

\section{PENDAHULUAN}

Buah cempedak (Artocarpus champeden sp.) merupakan komoditas perkebunan yang memiliki prospek cerah di masa yang akan datang khusunya untuk daerah Kalimantan, karena di samping dapat dimanfaatkan sebagai bahan pangan, juga dapat diproyeksikan sebagai bahan industri.

Cempedak adalah buah multimanfaat.

Daging buahnya kaya zat gizi, khususnya vitamin A. Kulit dan bijinya pun dapat dimakan dan dapat diolah sebagai pengganti bahan pangan, kulit batangnya sebagai antitumor dan antimalaria. 
Tanaman cempedak termasuk dalam famili Moraceae genus Artocarpus, seperti nangka yang merupakan tumbuhan dikotil dengan akar tunggang dan batang yang berkambium. Tanaman ini memiliki nilai ekonomis yang tinggi. Setiap bagian pada tanaman ini dapat dimanfaatkan. Kayunya berkualitas baik, kuat dan awet, sehingga kerap digunakan sebagai kayu bangunan, bahan perabotan rumah, atau bahan perahu. Kulit kayunya yang berserat dapat digunakan sebagai bahan tali, dan getahnya untuk memukat burung. Dari kayunya juga dapat dihasilkan bahan pewarna kuning. Buah dimakan dalam keadaan segar atau diolah terlebih dahulu.

Selama ini, di Indonesia, cempedak khususnya di daerah Kalimantan hanya dimanfaatkan sebagai makanan atau sayuran. Sementara usaha pemanfaatan yang lain, hanya bertaraf tradisional, untuk memenuhi kebutuhan konsumsi saja, seperti pemanfaatan kulit buah cempedak sebagai mandai, buahnya menjadi selai, sampai kayunya menjadi perabot rumah tangga. Padahal, bagian lain masih banyak bisa dimanfaatkan lebih lanjut untuk meningkatkan nilai gunanya.

Biji buah cempedak, sebenarnya mempunyai potensi yang tak kalah besar untuk dimanfaatkan. Dari pengamatan, biji cempedak biasanya berukuran sebesar ibu jari manusia. Ditutupi semacam lapisan lilin, biji ini memiliki tekstur yang padat berwarna putih. Kandungan karbohidrat yang dimiliki biji cempedak pun, cukup berbanding dengan yang ada pada tepung terigu. Selama ini biji dari buah cempedak kebanyakan dibuang begitu saja. Padahal dengan perlakuan khusus, bukan tidak mungkin biji ini ternyata dapat dikembangkan menjadi satu bentuk bahan pangan baru.

Berpegang pada data yang ada, biji cempedak, dengan segala kelebihannya dari segi tekstur maupun kandungan gizi buah cempedak, dianggap memiliki potensi besar untuk dikembangkan menjadi bahan pangan yang dapat dikonsumsi. Banyak yang bisa diolah dengan bahan dasar biji cempedak diantaranya bisa di buat sebagai susu, stik, perkedel, tepung. Adapun tujuan dari kegiatan ini adalah sebagai berikut:

1. Memberikan informasi kepada warga khususnya di Rt 34/ Rw 11 
Beruntung Jaya Kelurahan Sungai

Tiung kandungan gizi yang terdapat dari buah cempedak khususnya pada biji cempedak

2. Memberikan informasi kepada warga khususnya di Rt 34/ Rw 11 Beruntung Jaya Kelurahan Sungai Tiung olahan yang dapat di buat dengan bahan dasar biji pada buah cempedak

Dari segi jumlah, ketersediaan cempedak yang cukup melimpah di Indonesia khusunya wilayah Kalimantan menjadi kemudahan bagi masyarakat untuk memanfaatkannya. Tumbuhan yang tumbuh secara alami dan melimpah serta menyebar ini dapat dimanfaatkan oleh masyarakat Indonesia secara luas, yang daerahnya sesuai dengan sifat tumbuhnya.

Dari segi ekonomi, dengan pemanfaatan biji cempedak ini, kebutuhan masyarakat akan gizi akan dapat terpenuhi, karena dari harga pun, akan jauh lebih murah. Pengabdian masyarakat ini di harapkan mampu kedepannya membantu membuka peluang usaha bagi industri rumah tangga. Kualitas hasil pengolahan dari biji cempedak tentunya akan dapat bersaing dengan baik.

\section{METODE PELAKSANAAN}

Kegiatan Pengabdian Masyarakat ini dilakukan dengan cara pemberian informasi mengenai gizi yang terkandung dalam buah cempedak dan praktek pembuatan susu dan stik dengan bahan dasar dari biji cempedak yang dilakukan oleh dosen dan dibantu oleh mahasiswa kepada warga di $\begin{array}{llllll}\text { Beruntung Jaya } & \text { Rt } & 34 & \text { Rw } & 11\end{array}$ Kelurahan Sungai Tiung Kecamatan Cempaka. Kemudian dilaksanakan diskusi dan tanya jawab, tanya jawab dibagi ke dalam 2 sesi yaitu sesi pertama untuk pertanyaan warga kepada penyuluh dan sesi kedua pertanyaan panitia pengabdian masyarakat kepada warga. Di sesi lain dilakukan praktek pembuatan susu dan stik dengan bahan dasar dari biji cempedak. Sasaran dari kegiatan ini adalah warga di Beruntung Jaya Rt 34/ Rw 11Kelurahan Sungai Tiung Kecamatan Cempaka.

\section{PEMBAHASAN}

\section{Gambaran Umum Kegiatan}

Mata pencaharian merupakan aktivitas manusia untuk memperoleh taraf hidup yang layak dimana antara daerah satu dengan daerah yang lainnya berbeda sesuai dengan taraf 
kemampuan penduduk dan keadaan demografinya. Mata pencaharian penduduk Kelurahan Sungai Tiung sebagian besar adalah pendulang, petani dan peternak karena sebagian besar wilayah Kelurahan Sungai Tiung merupakan daerah pendulangan danpertanian. Selain itu ada juga masyarakat yang bekerja sebagai pedagang dan buruh di kota. Kegiatan Pengabdian masyarakat ini dilaksanakan di Beruntung Jaya Rt 34/ Rw 11 Kelurahan Sungai Tiung, Kecamatan Cempaka dengan sasaran ibu-ibu posyandu dan warga sekitar. Kegiatan dilaksanakan dalam 2 bentuk yaitu Kegiatan pertama adalah Pemberian Informasi Manfaat dan Kandungan Gizi yang terdapat pada buah Cempedak dan demontrasi berbagai olahan pangan dengan bahan utama biji Cempedak.Kegiatan pengabdian kali ini dikemas dalam bentuk pelatihan secara teori dengan materi kandungan gizi biji cimpedak, teknik pengolahan biji cimpedak menjadi susu, stik

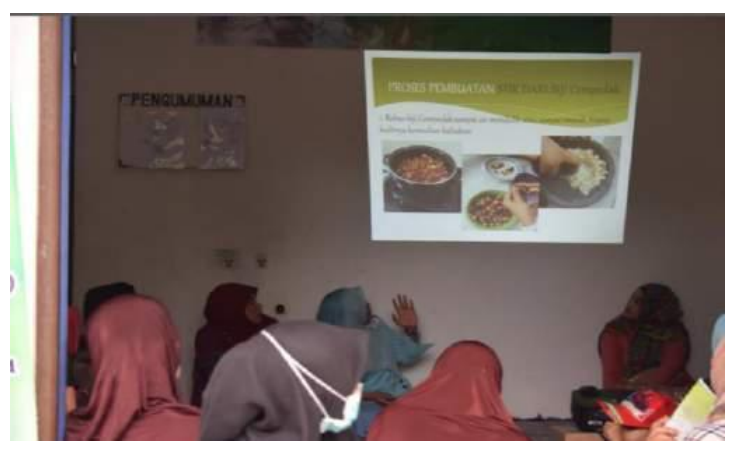

Gambar 1. Pemberian Informasi Cara PembuatanStik Dari Biji Cimpedak

$$
\text { Informasi teori tentang gizi dan }
$$
khasiat biji cimpedak menjadi dasar wawasan utama dalam pembutan susu. Buah cimpedak sebagai buah khas Kalimantan Selatan, yang hanya buah dan kulit yang bisa dimanfaatkan untuk makanan. Masyarakat belum familiar bahwabiji cimpedak dapat dimanfaatkan sebagai minuman kesehatan (susu) dan makanan ringan (stick). Dari segi komposisi gizi, bahan mentahbiji cempedak dapat dilihat pada tabel di bawah ini. 
Tabel 1. Komponen Gizi yang terdapat pada Biji Cempedak

\begin{tabular}{cc}
\hline Komponen Gizi & Biji Cempedak \\
\hline Energi $(\mathrm{kkal})$ & 165 \\
Protein $(\mathrm{g})$ & 4,2 \\
Lemak $(\mathrm{g})$ & 0,1 \\
Karbohidrat $(\mathrm{g})$ & 36,7 \\
Kalsium $(\mathrm{mg})$ & 33 \\
Fosfor $(\mathrm{mg})$ & 200 \\
Besi $(\mathrm{mg})$ & 1 \\
Air $(\mathrm{g})$ & 57,7 \\
\hline
\end{tabular}

Data diolah dari Drake, D.L., S.E. Gebhardt, R.H. Matthews, Composition of Foods: Cereal Grains and Pasta, United States Department of Agriculture serta Departemen Kesehatan RI.

Biji cempedak merupakan sumber karbohidrat $(36,7 \mathrm{~g} / 100 \mathrm{~g})$. Protein biji cempedak $(4,2 \mathrm{~g} / 100 \mathrm{~g})$ dapat dimanfaatkan sebagai bahan pangan yang potensial. Biji cempedak juga merupakan sumber mineral yang baik. Kandungan mineral per 100 gram Biji cempedak adalah fosfor (200 mg), kalsium (33 mg), dan besi (1,0mg). Sebagai salah satu bahan makanan, tepung yang diahasilkan dari biji cempedak tentu sangat mendukung dalam usaha pemenuhan gizi masyarakat. Berdasarkan kedua tabel tadi, salah satu contoh, fosfor yang dikandung cempedak sebesar $200 \mathrm{mg}$, berarti sepertiga dari standar AKG. Jika dikombinasikan dengan bahan makanan lain, biji cempedak berperan besar dalam pemenuhan gizi.
Berdasarkan uji laboratorium, kandungan fosfor dan kalsium susu biji cempedak lebih tinggi daripada susu kedelai. Sementara kadar lemaknya, justru lebih rendah, memperbanyak keluarnya ASI, mengobati mencret, campak, kolik kandung empedu, pencernaan lemah, dan dapat jadi bahan pembuat kue (Nuraini, 2011).

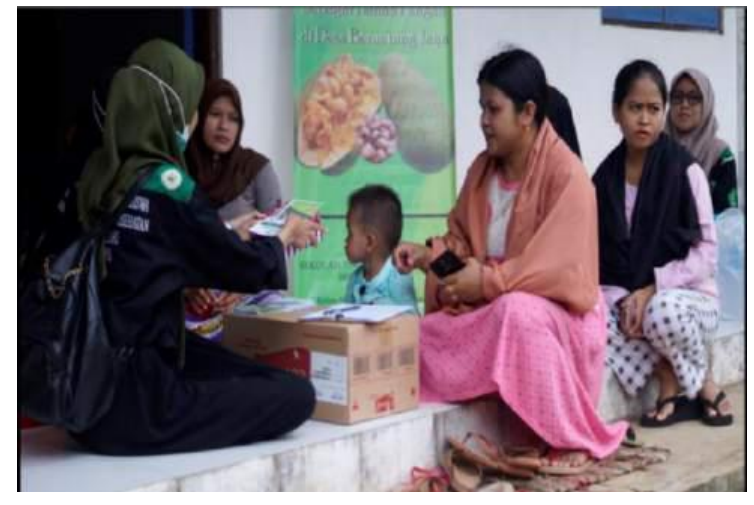

Gambar 2. Penyampaian Materi

Mengenai Kandungan Gizi dan Manfaat dari Biji Cimpedak 
Kegiatan kedua yang cimpedak antara lain tahap dilaksanakan adalah demontarsi merendaman biji cimpedak selama 12 berbagai macam olahan pangan dengan jam, tahap merebusan, tahap bahan utama biji Cempedak. Olahan menghalusan, tahap penyaringan. pangan yang di demontrasikan adalah cara pembuatan susu dan stik(cemilan) kripik yang bahan utamanya adalah biji Cempedak. Proses pembuatan susu biji Pemilihan biji cimpedak yang bagus menjadi perhatian utama sehingga susu atau stick dapat menjadi olahan yang sehat.

\section{Tabel 2. Kadar Protein dan Kalsium Susu Cimpedak}

\section{Dengan Varian Rasa Buah Naga}

\begin{tabular}{llc} 
No. & Nama Bahan & Jumlah digunakan \\
\hline 1. & Biji Cimpedak & $1 \mathrm{~kg}$ \\
2. & Gula & $1 / 2 \mathrm{~kg}$ \\
3. & Air & $3 \mathrm{lt}$ \\
\hline
\end{tabular}

Kadar Protein : $\pm 42 \%$, kalsium $\pm 33 \mathrm{Kkal} / \mathrm{kg}$

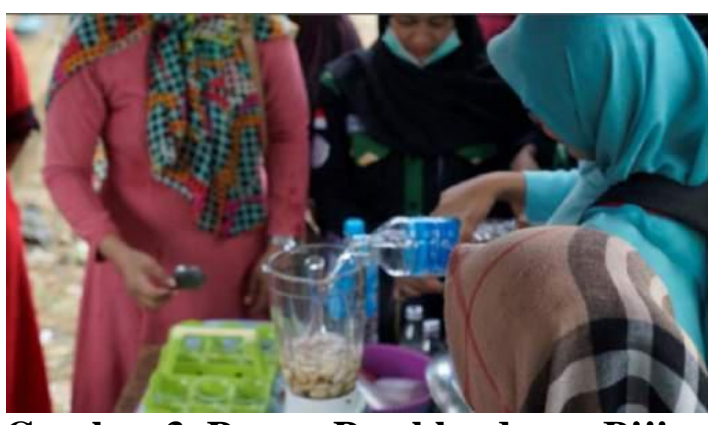

Gambar 3. Proses Pemblenderan Biji Gambar

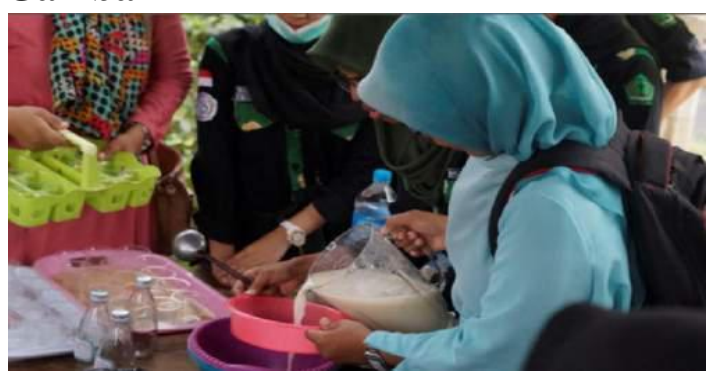

Gambar 4. Proses Penyaringan Cimpedak Untuk Pembuatan Susu

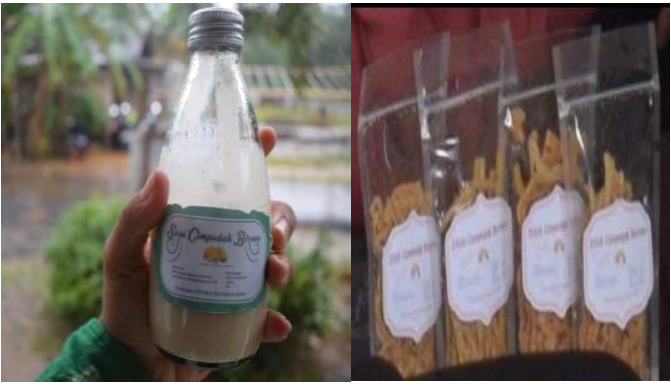

Gambar 5. Biji Cimpedak Untuk Pembuatan Susu dan Stick

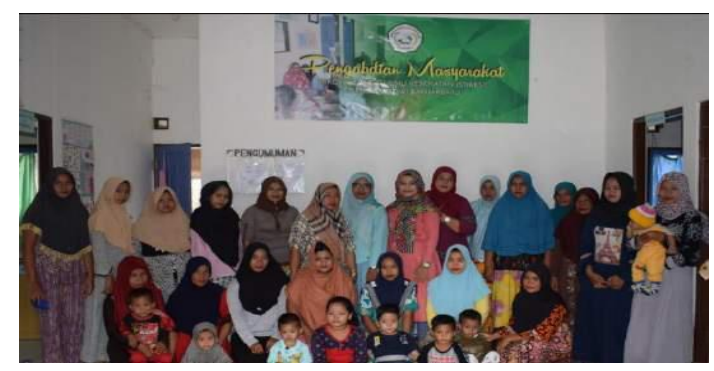

Gambar 6. Prosesi Foto Bersama masyarakat 
Dari hasil kegiatan pengabdian ini, secara umum warga masyarakat di desa binaan STIKES Borneo Lestari sudah memahami cara pemanfaatn biji cimpedak dengan berbagai olahan, antara lain, susu dan stick (makanan ringan). Hasil pengamatan antusias warga untuk memanfaatkan biji cimpedakkarena dapat berkhasiat sebagai meredakan diare, campak dan dapat memperbanyak ASI. Selain itu, biji cimpedak mempunyai kandungan protein, kalsium dan fosfor yang tinggi dibandingkan susu kedelai dengan kandungan lemak yang rendah.

\section{Keberlanjutan}

Sebagian besar ibu-ibu warga desa Sungai Tiung yang mengikuti kegiatan pengabdian masyarakat ini mempunyai harapan keberlanjutan dari program ini yaitu dalam bentuk pembinaan usaha desa, dimana usaha tersebut bukan saja dalam hal produksi susu biji cimpedak, tetapi juga meliputi membudidayaan buah cimpedak. Sehingga oalahan cimpedak yang dihasilkan berupa produk yang mudah dipasarkan.

\section{Beberapa Permasalahan lain yang terekam}

Beberapa permasalahan yang terekam setelah kegiatan pengabdian ini adalah keterbatasan modal bagi warga, kurangnya pelatihan penjualan online. Walaupun demikian warga masih optimissaling memberikan motivasi untuk membuka usaha baru bagi warga cukup menonjol dan mempunyai kemauan untuk maju.

\section{KESIMPULAN}

Dari kegiatan pengabdian masyarakat secara keseluruhan kegiatan berhasil dilakukan dilihat dari antusiasme warga yang terlihat dari banyaknya pertanyaan yang diajukan dan para peserta yang komunikatif dan sangat mendukung terhadap program kegiatan yang dilaksanakan.

\section{DAFTAR PUSTAKA}

Anshari, dkk. 2010. Pemanfaatan Biji Cimpedak Sebagai Alternatif Pengganti Tepung Terigu Dengan Kualitas Gizi Tinggi. PKM-GT. FMIPA-UM

Astawan, Made. 2009. Cempedak Sahabat Mata. http://www. cybertainment.cbn.net.id [diakses 30 September 2019]

Nuraini, D.N. 2011. Aneka Manfaat Kulit Buah dan Sayuran. Andi: Yogyakarta 
Jurnal Pengabdian Al-Ikhlas

ISSN : 2461-0992

Volume 5 Nomor 2, April 2020 